\title{
Kinetic Modeling of Supercritical Fluid Extraction of Betel Nut
}

\author{
M. S. H. Ruslan ${ }^{1}$, Z. Idham ${ }^{2}$, M. A. A. Zaini ${ }^{2}$, L. Y. Yian², and M. A. C Yunus ${ }^{2 *}$ \\ ${ }^{1}$ Department of Chemical Engineering, Universiti Teknologi PETRONAS, \\ 32610 Bandar Sri Iskandar, Perak, Malaysia \\ ${ }^{2}$ Centre of Lipid Engineering \& Applied Research (CLEAR), Ibnu Sina Institute for \\ Scientific \& Industrial Research (Ibnu Sina ISIR) Universiti Teknologi Malaysia, \\ 81310 UTM Johor Bahru, Malaysia \\ Email: azizi@cheme.utm.my \\ Phone: +607-5532727; Fax: +6075532726
}

\begin{abstract}
Supercritical fluid extraction is an advanced extraction technique that suitable for heat sensitive and active compound material from plants and herbs. Understanding the effect of extraction parameters on mass transfer coefficient at solid and fluid phase can determine the dominating extraction regime thus performance of the extraction may be enhanced. The aim of this research was to determine the mass transfer coefficient in solid and fluid phase using kinetic modelling approach. Grounded betel nuts were treated with supercritical carbon dioxide with 5\% methanol as co-solvent to determine its mass transfer coefficient in solid and fluid phase for the following extraction conditions; pressure, 20 to $30 \mathrm{MPa}$; temperature, 50 to $70{ }^{\circ} \mathrm{C}$; and flow rate, 2 to 4 $\mathrm{mL} / \mathrm{min}$. Simplified Sovová model was coupled with Broken and Intact Cell model to determine the mass transfer coefficients. Results show the mass transfer coefficients of solid phase and liquid phase are in the ranges of 0.00015 to $0.00353 \mathrm{~m}^{3} / \mathrm{min}$ and 0.3497 to $3.9623 \mathrm{~m}^{3} / \mathrm{min}$, respectively. The overall absolute average relative deviation was observed to be $7.39 \%$.
\end{abstract}

Keywords: Areca catechu; betel nut; supercritical fluid extraction; kinetic model; mass transfer coefficient.

\section{INTRODUCTION}

Supercritical fluid extraction (SFE) is an advanced extraction technique with high selectivity. The selectivity of the process depends on the extraction conditions and solvent used as the extractor. Carbon dioxide is widely chosen as the main solvent in SFE due to its low critical condition, inert, inflammable, and inexpensive. While modifier such as methanol can be added to enhance the selectivity and polarity of the fluid [1]. SFE has successfully been conducted on the extraction of interest and bioactive compounds from palm fatty acid [2], cardoon [3], peppermint [4], pitanga fruits [5], peach [6], dandelion leaves [7], abajeru [8], guava seeds [9], coffee beans [10], neem seeds [11], horsetail [12], jatropha seeds [13], garlic flakes [14], tomato [15], Mucuna seeds, [16], vanilla [17], celery seeds [18], paprika [19], hemp seed [20], and coconut flesh [21].

Areca catechu or betel nut is a plant from the arecaceae family which grows widely in India and south-east Asia region. The seeds are traditionally used for cigarette 
and the leaves are used as food packaging [22]. One of the compound of interest that can be obtained from betel nut is catechin, is a polyphenols compound which contains anti-oxidant, anti-depressant, hypoglycaemic, wound healing, and anti-HIV properties [23]. Other sources of catechin from local plants are tea leaves and onion skins [24]. The highest catechin content in betel nut was reported as $0.0844 \mathrm{mg}$ catechin/g sample obtained using accelerated water extraction [25]. Apart from having multiple therapeutic properties, the catechin monomers in the form of tannins give the betel a reddish brown colour that is a promising source of natural colorant [25].

Cross over pressure or retrograde solubility plays an important role in determining the suitable operating condition for several sample of extract. It is a phenomenon in SFE process where the dominant effect of solvation power shift to effect of solute vapor pressure. The cross over pressure varies from one sample to the other. To date, no study on determining the cross over pressure for betel nut has been conducted. Thus, determining the cross over pressure was essential in understanding the mass transfer regime for SFE processes.

The SFE experimental results can be interpreted by equation or model developed based on several assumptions to represent the actual extraction process. The models commonly used to describe the SFE data can be categorized as empirical model and kinetic model. The kinetic model is applied to the extraction profile to study the effect of extraction parameter on the mass transfer coefficient of solute in solid phase and fluid phase. The mostly used models are Sovová model [26] and Broken and Intact Cell [27].

To date, there are no study conducted regarding the solubility of betel nuts extract in supercritical fluid and data for mass transfer coefficient in solid phase and fluid phase was not established. This study aims to determine the conditions for the highest mass transfer coefficient in solid phase and fluid phase to preferably demonstrate the best extraction conditions. The effect of extraction parameters was also discussed.

\section{EXPERIMENTAL SET UP}

\section{Materials}

Betel nuts were purchased from local market in Pulau Pinang, Malaysia. The sample was dried and ground using hammer-grinder (POLYMIX® PX-MFC 90D, Switzerland) to a desired average particle size $(177.5 \mu \mathrm{m})$. A $99.9 \%$ purity $\mathrm{CO}_{2}$ was obtained from KRAS Instrument, Malaysia for SFE process. Methanol, AR grade supplied by QRec was used as the modifier for the study.

\section{Method}

Pressurized $\mathrm{CO}_{2}$ gas was introduced into a $1.5 \mathrm{~m}$ coil located inside an oven (Memmert) using constant flow pump (Lab Alliance, Series II Pump) to achieve the desired operating temperature. A $50 \mathrm{~mL}$ extraction cell loaded with $10 \pm 1$ grams of sample with known volume of modifier was fitted between the coil and back pressure regulator (JASCO, Model BP-2080). The experimental set up was as per illustrated in Figure 1. The extraction was conducted for 1 hour of extraction regime with every 10 minutes fractionation. One Factor at a Time (OFAT) design was used for the variation of 3 variables with 3 level values as shown in Table 1. 


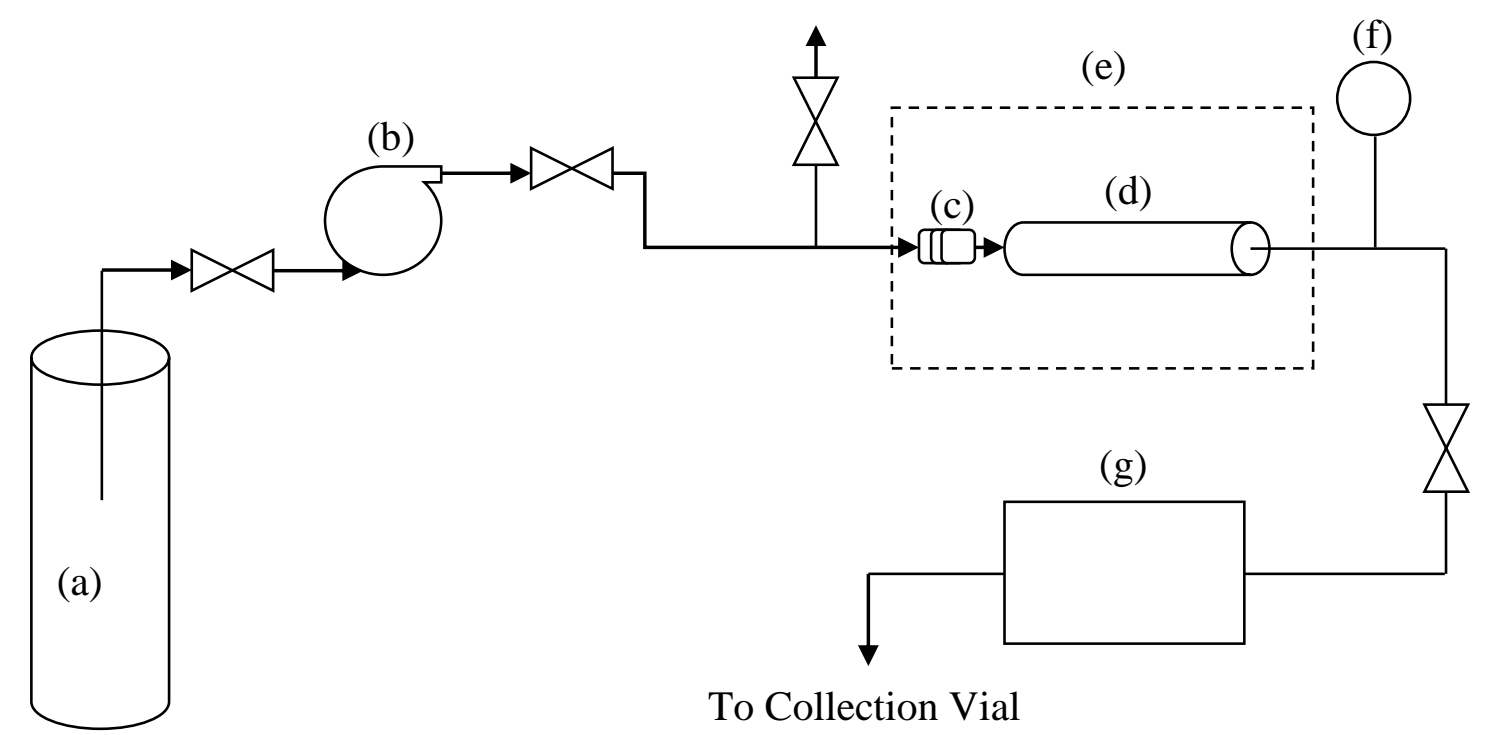

Figure 1: Schematic diagram of SFE apparatus with (a) $\mathrm{CO}_{2}$ cylinder, (b) $\mathrm{CO} 2$ pump, (C) heated coil, (d) extraction cell, (e) oven, (f) pressure gauge, (g) back pressure regulator [28].

Table 1: Parameters and level values used for the study.

\begin{tabular}{lccc}
\hline Parameter (unit) & $\begin{array}{c}\text { High Value } \\
(+1)\end{array}$ & $\begin{array}{c}\text { Middle Value } \\
(0)\end{array}$ & $\begin{array}{c}\text { Low Value } \\
(-1)\end{array}$ \\
\hline Flow Rate $(\mathrm{mL} / \mathrm{min})$ & 2 & 3 & 4 \\
Temperature $\left({ }^{\circ} \mathrm{C}\right)$ & 50 & 60 & 70 \\
Pressure $(\mathrm{MPa})$ & 20 & 25 & 30 \\
\hline
\end{tabular}

\section{Kinetic Modelling}

Kinetic models were used to fit the extraction profile. The model is generally divided into three equations which represent the three stages of extraction profile. Broken and Intact Cell (BIC) model with 4 adjustable parameters was adapted in this study. Derivation of this model was described elsewhere [29]. The model assumes that the process is isobaric and isothermic, the axial dispersion of solvent in extraction bed is neglected, samples have broken and intact cell, and mass transfer is divided in to solid phase and fluid phase [30]. Extraction regime was divided into three extraction regime namely, equilibrium controlled phase, intermediate phase and diffusion controlled phase. Broken cell is formed due to the grinding effect. High saturation of solute located at the broken cell known as outer layer of sample, while the inner layer of solute located in the intact part of the sample that is not affected or crushed by the grinding process. For kinetic study, the equations for this model are shown in Eq. (1) to Eq. (7). 


$$
\begin{aligned}
& \frac{\mathrm{E}}{\mathrm{Nx}_{0}}=\left\{\begin{array}{cr}
\psi[1-\exp (-\mathrm{Z})] & \text { for } \psi<\frac{\mathrm{G}}{\mathrm{Z}} \\
\psi-\frac{\mathrm{G}}{\mathrm{Z}} \exp \left[\mathrm{z}\left(\mathrm{h}_{\mathrm{k}}-1\right)\right] & \text { for } \frac{\mathrm{G}}{\mathrm{Z}} \leq \psi \leq \psi_{\mathrm{k}} \\
1-\frac{1}{\mathrm{Y}} \ln \left\{1+[\exp (\mathrm{Y})-1] \exp \left[\mathrm{Y}\left(\frac{\mathrm{G}}{\mathrm{Z}}-\psi\right)\right](1-\mathrm{G})\right\} & \text { for } \psi \geq \psi_{\mathrm{k}}
\end{array}\right. \\
& \psi=\frac{\mathrm{tQy}_{\mathrm{r}}}{\mathrm{Nx}_{0}} \\
& \psi_{\mathrm{k}}=\frac{\mathrm{G}}{\mathrm{Z}}+\frac{1}{\mathrm{Y}}\left[1+\frac{\{\exp [\mathrm{Y}(\psi-\mathrm{G})\}-1\}}{\mathrm{G}}\right] \\
& h_{k}=\frac{1}{Y}\left[1+\frac{\left\{\exp \left[Y\left(\psi-\frac{G}{Z}\right)\right\}-1\right\}}{G}\right] \text { for } \frac{G}{Z} \leq \psi \leq \psi_{k} \\
& \mathrm{Y}=\frac{\mathrm{Nk}_{\mathrm{s}} \mathrm{ax}_{0}}{\mathrm{Q}(1-\varepsilon) \mathrm{y}_{\mathrm{r}}} \\
& Z=\frac{N k_{f} a \rho_{f}}{Q(1-\varepsilon) \rho_{s}} \\
& \varepsilon=1-\frac{\rho_{\mathrm{A}}}{\rho_{\mathrm{S}}}
\end{aligned}
$$

where $\mathrm{E}(\mathrm{g})$ is the extraction yield, $\mathrm{N}(\mathrm{g})$ is the weight of solute-free sample, $\varepsilon$ is the porosity of sample, $\rho_{\mathrm{A}}\left(\mathrm{kg} / \mathrm{m}^{3}\right)$ is apparent density of sample, $\rho_{\mathrm{S}}\left(\mathrm{kg} / \mathrm{m}^{3}\right)$ is real density of sample, $\psi$ and $\psi_{\mathrm{k}}$ are dimensionless times, $\mathrm{h}_{\mathrm{k}}$ is the dimensionless coordinate which separates the equilibrium region and diffusion region, $\mathrm{Q}(\mathrm{g} / \mathrm{min})$ is solvent flow rate, $\mathrm{G}$, $\mathrm{Z}$ and $\mathrm{Y}$ are adjustable parameters, and $\mathrm{k}_{\mathrm{f}} \mathrm{a}$ and $\mathrm{k}_{\mathrm{s}} \mathrm{a}$ are mass transfer coefficient $\left(\mathrm{m}^{2} / \mathrm{m}^{3} . \mathrm{min}\right)$ in fluid phase and solid phase, respectively. Apparent density was determined by the ratio of sample weight to the volume of extraction cell, while real density was measured by the volume of solvent displaced by known weight of sample. G, Z, Y and $\psi_{\mathrm{k}}$ are the adjustable parameters for BIC model. Reducing the number of adjustable parameters will enhance the capability of the model in improving the relative deviation. Thus, the value of $\mathrm{G}$ maybe calculated using simplified Sovová model as shown in Eq. (8) until Eq. (12) [31].

$$
\begin{aligned}
& \frac{E}{N_{m}}=\left\{\begin{array}{cc}
q_{s} y_{s} & 0 \leq q<q_{c} \\
x_{u}\left(1-C_{1} \exp \left(-C_{2} q\right)\right. & q \geq q_{c}
\end{array}\right. \\
& q=M / N_{m} \\
& M=\rho V \\
& N_{m}=\left(1-c_{u}\right) N \\
& x_{u}=c_{u} /\left(1-c_{u}\right)
\end{aligned}
$$


where $\mathrm{q}$ is the relative amount of passed solvent, $\mathrm{q}_{\mathrm{c}}$ is the relative amount of passed solvent in the fast extraction period, $\mathrm{y}_{\mathrm{s}}$ (g extract/g fluid) is the solubility of extract, $\mathrm{x}_{\mathrm{u}}$ is the weight fraction of untreated solid, $M(\mathrm{~g})$ is the weight of passed solvent, $\mathrm{c}_{\mathrm{u}}$ is the weight fraction of total solute content in sample, $\rho$ is density of fluid in $\mathrm{g} / \mathrm{mL}, \mathrm{V}(\mathrm{mL})$ is the volume of passed solvent, $\mathrm{N}(\mathrm{g})$ is the weight of solid sample, and $\mathrm{C}_{1}$ and $\mathrm{C}_{2}$ are the adjustable parameters for the simplified Sovová model. After the values of $\mathrm{C}_{1}, \mathrm{C}_{2}$ and $\mathrm{q}_{\mathrm{c}}$ were obtained, Eq. (13) was used to determine the value of $\mathrm{G}$ for each extraction condition.

$\mathrm{G}=1-\mathrm{C}_{1} \exp \left(\frac{-\mathrm{C}_{2} \mathrm{q}_{\mathrm{c}}}{2}\right)$

\section{Objective Function}

Extraction yield values generated by the models ( $\mathrm{y}_{\text {calculated}}$ ) were compared with the experimental data ( $y_{\text {experimental }}$ ). An error minimization method was used to minimize the deviation between the observed and the predicted value. The minimization of Absolute Average Relative Deviation (AARD) value is shown in Eq. (14). The objective was to obtain the smallest possible AARD value rendering a small deviation for the model to be in good agreement with the extraction profile. Thus, the model with the lowest AARD value was chosen as the best model to represent the extraction behavior.

$\mathrm{AARD}=\frac{1}{\mathrm{~N}} \sum_{\mathrm{i}=1}^{\mathrm{N}}\left|\frac{\mathrm{y}_{\text {calculated }^{-}} \mathrm{y}_{\text {experimental }}}{\mathrm{y}_{\text {experimental }}}\right| \times 100 \%$

\section{RESULTS AND DISCUSSION}

\section{Solubility of Extracts in Supercritical Fluid}

Solubility of extracts in supercritical fluid were obtained from the first part of the extraction curve of extraction yield versus time. Figure 2 shows the solubility of extracts in supercritical fluid at different flow rates. Retrograde solubility was observed at $20 \mathrm{MPa}$ for all flow rates studied. At constant temperature of $50^{\circ} \mathrm{C}$, the solubility increases from $1.20 \pm 0.30 \mathrm{~g}$ extract / L fluid to $2.23 \pm 0.17 \mathrm{~g}$ extract / L fluid as the pressure increases from 20 to $30 \mathrm{MPa}$. An average increase of $45 \%$ can be observed for all flow rates. However, at $70^{\circ} \mathrm{C}$, the increase of $67 \%$ may be observed as solubility increases from $1.27 \pm 0.30 \mathrm{~g}$ extract / $\mathrm{L}$ fluid to $3.80 \pm 0.50 \mathrm{~g}$ extract / $\mathrm{L}$ fluid as pressure increases from 20 to $30 \mathrm{MPa}$.

The increase in temperature increases the solubility of extracts in supercritical

fluid. Retrograde solubility or cross over pressure has an inverse dominant effect of pressure to temperature. Below the cross over pressure, the dominant effect is pressure. As the pressure increased, the density of supercritical fluid increases thus, increasing the solvating power of fluid into the sample matrix. The increase in temperature decreases the solvent density, hence lowering the solvating power of fluid. But, above the cross over pressure, the extracts solubility depends on the vapor pressure of the solute. Increasing temperature causes the vapor pressure of solute to increase thus favour the extraction process. This tip off between the major effects of density of solvent to the vapor pressure of solute was referred as retrograde solubility. The cross over pressure is 
not similar for all samples. As reported by previous researchers, the cross over pressure values of cinnamic acid, phenoxyacetic acid, 4-methoxyphenylacetic acid and clotrimazole are 16.2 to $16.8 \mathrm{MPa}, 13.4$ to $14 \mathrm{MPa}, 16$ to $16.7 \mathrm{MPa}$ and $20 \mathrm{MPa}$, respectively $[31,32]$.

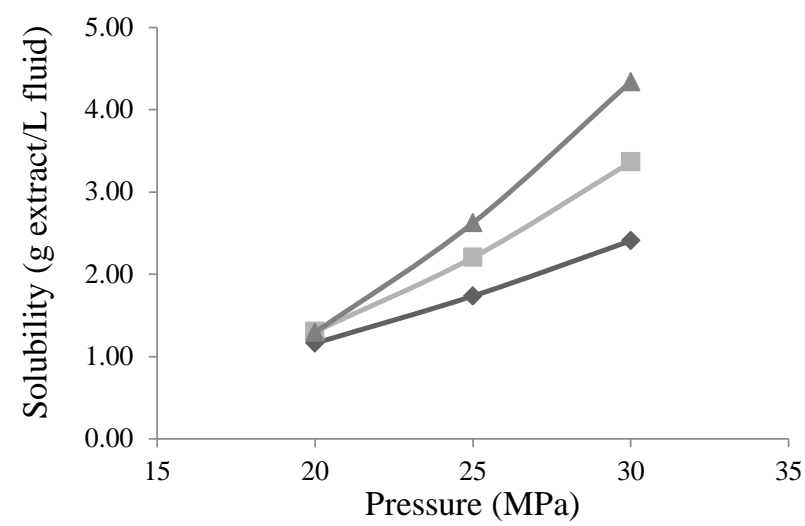

(a)

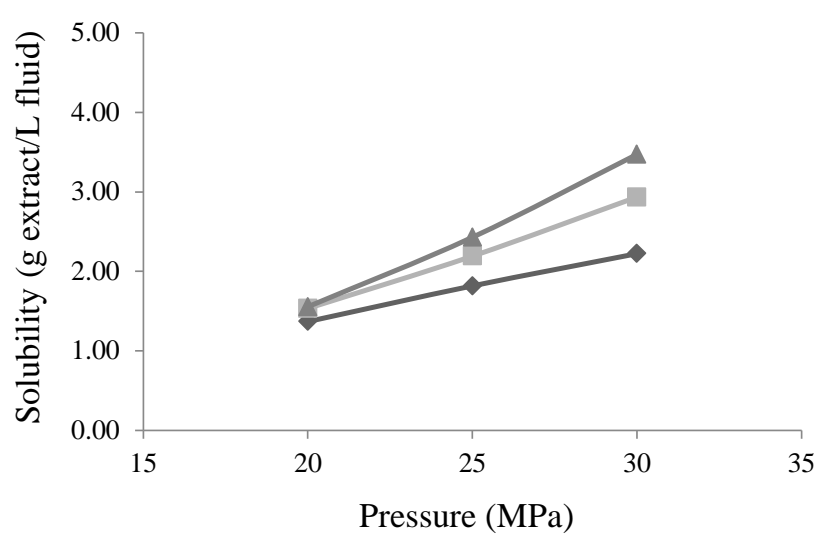

(b)

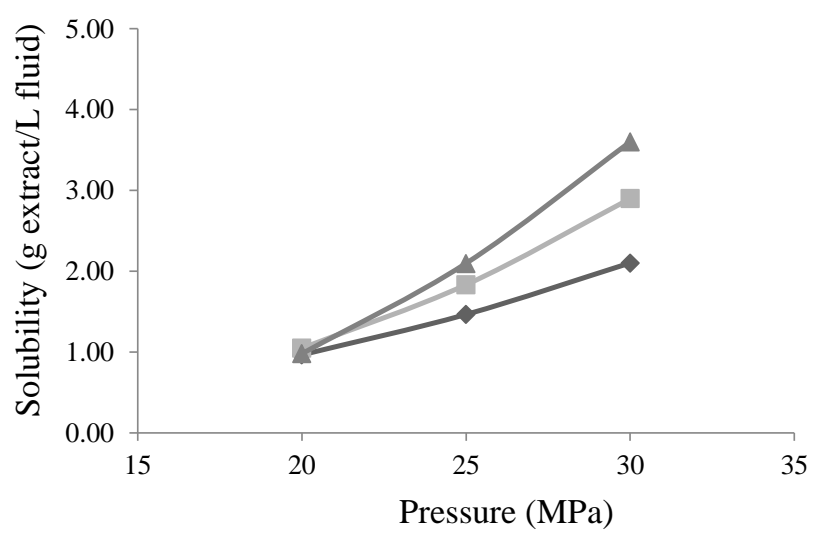

(c)

Figure 2. Solubility of extract in supercritical fluid at constant flow rate of (a) $2 \mathrm{~mL} / \mathrm{min}$ (b) $3 \mathrm{~mL} / \mathrm{min}$ (c) $4 \mathrm{~mL} / \mathrm{min}\left(\bullet\right.$ for $50{ }^{\circ} \mathrm{C}, \boldsymbol{\square}$ for $60^{\circ} \mathrm{C}$ and $\boldsymbol{\Delta}$ for $70{ }^{\circ} \mathrm{C}$ ) 


\section{Kinetic Models}

The extraction curve was divided into three phases as shown in Figure 3. Phase I is the equilibrium region where the saturated solute present at the outer layer of sample was extracted $(0-20 \mathrm{~min})$. It can be observed that $70 \%$ from the total extractable content is extracted in the first 20 minutes for all cases. While the other $30 \%$ extracted within the next 40 minutes. This shows that most of the extracts is located in the outer layer of the sample matrix. Equilibrium controlled region dictates the extraction regime during the first 20 minutes of extraction. Table 2 shows the $\mathrm{k}_{\mathrm{fa}}$ value which represents the equilibrium-controlled region, is higher compared to the $\mathrm{k}_{\mathrm{sa}}$ value which represent the diffusion-controlled region. At constant temperature and pressure of $70^{\circ} \mathrm{C}$ and $30 \mathrm{MPa}$, the $\mathrm{k}_{\mathrm{fa}}$ value is $1.20,2.82$ and $3.93 \mathrm{~m}^{3} / \mathrm{min}$ for flow rate of 2,3 and $4 \mathrm{~mL} / \mathrm{min}$, respectively. Comparatively to the $\mathrm{k}_{\mathrm{sa}}$, the value is $0.00094,0.00086$ and $0.0011 \mathrm{~m}^{3} / \mathrm{min}$ as the flow rate increases from 2 to $4 \mathrm{~mL} / \mathrm{min}$. This data supports the plotted data by showing the equilibrium-controlled region dominates the extraction regime substantially.

The extracts are mostly located at the outer layer of the surface matrix making it easily accessible for the fluid to extract it. Several reports on other mass transfer coefficient in solid and fluid phase have been reported such as $7.85 \times 10^{-6} \mathrm{~m} / \mathrm{s}$ and 6.56 $\times 10^{-9} \mathrm{~m} / \mathrm{s}$ for Pistacia khinjuk [33], $14.1 \times 10^{-3} \mathrm{~s}^{-1}$ and $1.26 \times 10^{-4} \mathrm{~s}^{-1}$ for sunflower seed [34], $6.298 \times 10^{-3} \mathrm{~min}^{-1}$ and $1.541 \times 10^{-2} \mathrm{~min}^{-1}$ for crambe seed [35], $5.73 \times 10^{-3} \mathrm{~s}^{-1}$ and $2.23 \times 10^{-4} \mathrm{~s}^{-1}$ for hops [36] and $0.333 \mathrm{hr}^{-1}$ and $13.2 \times 10^{-2} \mathrm{~h}^{-1}$ for Quercus cerrus cork [37], respectively. For this study, as the increases of pressure, temperature and flow rate increases, the $\mathrm{k}_{\mathrm{fa}}$ value also increases. This is because the condition permits more interaction between solute and solvents by altering the density of solvents, increasing the solvation power of solvent, increasing the vapour pressure of solute and removing the film resistance for better mass transfer.

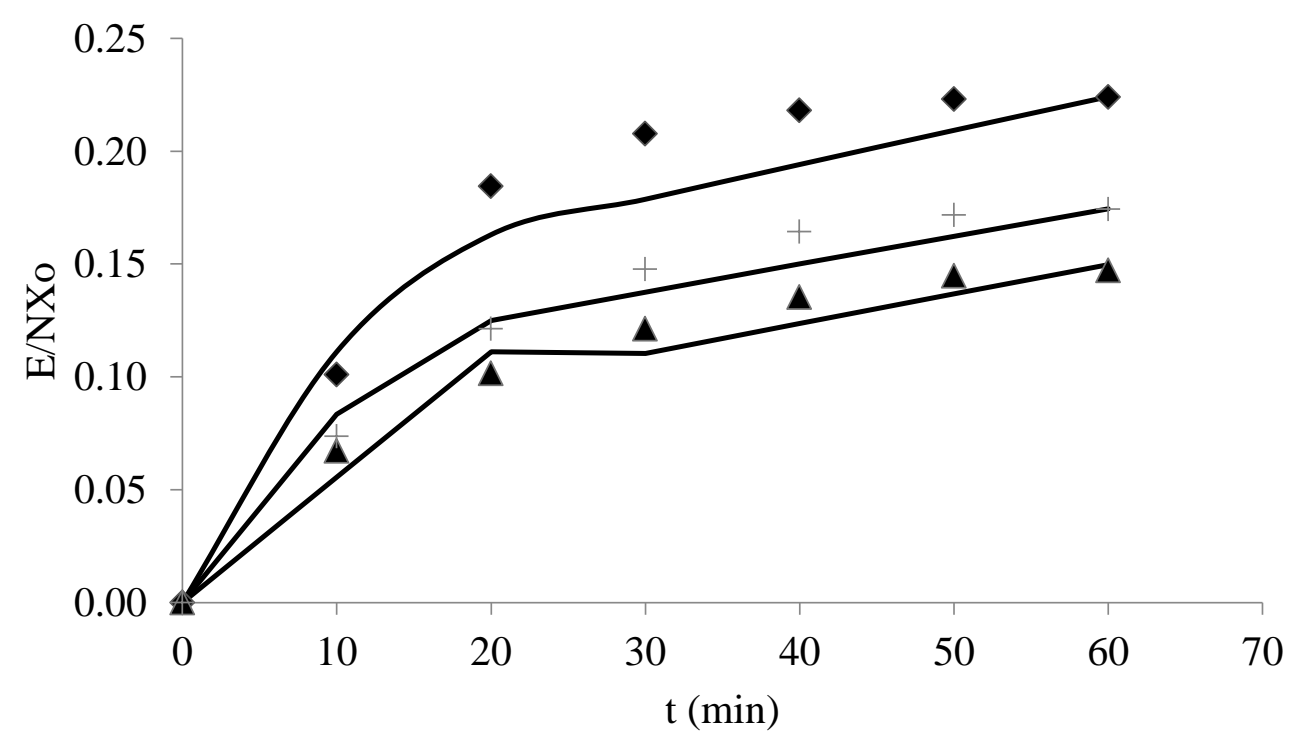

Figure 3. Extraction profile of betel nuts using supercritical fluid at constant temperature of $70^{\circ} \mathrm{C}$ and $30 \mathrm{MPa}$ (with (४) $2 \mathrm{~mL} / \mathrm{min}(+) 3 \mathrm{~mL} / \mathrm{min}(\boldsymbol{\Delta}) 4 \mathrm{~mL} / \mathrm{min}(-)$ BIC model). 
Table 2: Mass transfer coefficient in fluid phase and solid phase.

\begin{tabular}{|c|c|c|c|c|c|}
\hline $\begin{array}{l}\text { Flow Rate } \\
(\mathrm{mL} / \mathrm{min})\end{array}$ & $\begin{array}{c}\text { Temperature } \\
\left({ }^{\circ} \mathrm{C}\right)\end{array}$ & $\begin{array}{c}\text { Pressure } \\
(\mathrm{MPa})\end{array}$ & $\begin{array}{c}k_{s} a \\
\left(\mathrm{~m}^{3} / \mathrm{min}\right)\end{array}$ & $\begin{array}{c}k_{f} a \\
\left(\mathrm{~m}^{3} / \mathrm{min}\right)\end{array}$ & $\operatorname{AARD}(\%)$ \\
\hline \multirow{9}{*}{2} & \multirow{3}{*}{50} & 20 & 0.00149 & 0.3497 & 4.48 \\
\hline & & 25 & 0.00243 & 0.4773 & 9.52 \\
\hline & & 30 & 0.00063 & 0.5325 & 6.37 \\
\hline & \multirow{3}{*}{60} & 20 & 0.00015 & 0.6796 & 5.14 \\
\hline & & 25 & 0.00071 & 0.7677 & 6.42 \\
\hline & & 30 & 0.00144 & 0.8517 & 18.25 \\
\hline & \multirow{3}{*}{70} & 20 & 0.00191 & 0.8735 & 4.79 \\
\hline & & 25 & 0.00085 & 0.9698 & 5.00 \\
\hline & & 30 & 0.00094 & 1.2016 & 8.60 \\
\hline \multirow{9}{*}{3} & \multirow{3}{*}{50} & 20 & 0.00207 & 1.2667 & 11.87 \\
\hline & & 25 & 0.00353 & 1.9571 & 6.76 \\
\hline & & 30 & 0.00069 & 2.4555 & 6.33 \\
\hline & \multirow{3}{*}{60} & 20 & 0.00156 & 1.6409 & 13.68 \\
\hline & & 25 & 0.00124 & 2.0053 & 5.72 \\
\hline & & 30 & 0.00128 & 2.7116 & 5.77 \\
\hline & \multirow{3}{*}{70} & 20 & 0.00123 & 1.7452 & 7.29 \\
\hline & & 25 & 0.00104 & 2.1591 & 7.74 \\
\hline & & 30 & 0.00086 & 2.8185 & 6.18 \\
\hline \multirow{10}{*}{4} & \multirow{3}{*}{50} & 20 & 0.00276 & 1.9989 & 7.84 \\
\hline & & 25 & 0.00081 & 2.2817 & 4.23 \\
\hline & & 30 & 0.00082 & 3.2728 & 2.87 \\
\hline & \multirow{3}{*}{60} & 20 & 0.00141 & 2.1924 & 5.92 \\
\hline & & 25 & 0.00104 & 2.6658 & 3.20 \\
\hline & & 30 & 0.00258 & 3.6185 & 12.53 \\
\hline & \multirow{3}{*}{70} & 20 & 0.00252 & 2.3319 & 7.33 \\
\hline & & 25 & 0.00107 & 2.7996 & 6.81 \\
\hline & & 30 & 0.00111 & 3.9623 & 8.82 \\
\hline & \multicolumn{4}{|c|}{ Overall AARD } & 7.39 \\
\hline
\end{tabular}

The extraction rate was controlled by the solubility of solute in the supercritical fluid until it reaches $\mathrm{G} / \mathrm{Z}$ (dimensionless time). As the solute from the outer layer depletes, the intermediate phase begins. Separation of phases is given by a transition separator $h_{k}$, which divided the equilibrium-controlled region with the diffusioncontrolled region. The extraction phase was from $20-30 \mathrm{~min}$ as shown in Figure 3. Phase II given by the transition region indicates the flow of solvent through the inner layer of sample matrix until it reaches $\psi_{\mathrm{k}}$ (dimensionless time). The extraction then moves Phase III, i.e., the diffusion-controlled region. Here, the extraction is highly dependent on the diffusivity of solvent in solid matrix to extract solute located in the intact cell. In normal cases, the value of $\mathrm{k}_{\mathrm{fa}}$ will be greater than $\mathrm{k}_{\mathrm{sa}}$ because the mass transfer in fluid phase (equilibrium-controlled region) is faster than that in solid phase (diffusion-controlled region). Extraction was rapid in the fluid phase due to abundant amount of solute present in the outer layer of sample. Also, the diffusion path from 
solvent to solute was shorter compared to the penetration of solute to the inner layer of sample in solid phase.

Table 2 shows the result of kinetic modelling using simplified Sovová model and BIC model with overall AARD value of $7.39 \%$. The kinetic modelling was conducted to obtain the mass transfer coefficient values in solid and fluid phase. It can be seen in Table 2 that the values of mass transfer coefficient in solid phase are significantly lower than the mass transfer coefficient on fluid phase. This indicates that the extraction regime is dominated by the equilibrium-controlled region instead of the diffusion-controlled region. This shows that the solubility of solute in supercritical fluid is essential in the extraction process instead of the diffusivity of solute in the solid matrix. Thus, the discussions are focused on the fluid phase instead of the solid phase.

At constant temperature of $70^{\circ} \mathrm{C}$ and pressure if $30 \mathrm{MPa}$, as flow rate increase from 2 to $4 \mathrm{~mL} / \mathrm{min}$, the mass transfer coefficient in fluid phase increases from 1.2016 $\mathrm{m}^{3} / \mathrm{min}$ to $3.9623 \mathrm{~m}^{3} / \mathrm{min}$. The increase of flow rate shows a growth of $69.9 \%$ Increasing the solvent flow rate increases the saturation of solvent in the extraction cell. The increase on volume increases the interaction of solute and solvent hence enhancing the mass transfer from the solid matrices to the fluid bulk. Increasing the solvent flow rate also reduces the film resistance between the wall of sample thus hence increasing the mass transfer rate.

As the increase of operating pressure at constant temperature and solvent flow rate, the mass transfer fluid phase increases. Increment of 20 to $40 \%$ can be observe Table 2. At $70^{\circ} \mathrm{C}$ and $4 \mathrm{~mL} / \mathrm{min}$, the mass transfer coefficient in fluid phase increases from $2.3319 \mathrm{~m}^{3} / \mathrm{min}$ to $3.98623 \mathrm{~m}^{3} / \mathrm{min}$ as pressure was increase from 20 to $30 \mathrm{MPa}$. Increasing the operating pressure increases the density of solvent. This causes the solvent to be packed together and increases the solvating power of solvent. The condensed fluid extracts the solute from sample efficiently, thus increasing the mass transfer coefficient as the pressure increased at constant temperature and flow rate. The results obtained was similar with a trend observe in extraction of rosemary using supercritical carbon dioxide [38]. The highest yield was observed at approximately 2.1 wt $\%$ of extraction yield operated at $50^{\circ} \mathrm{C}$ and 400 bar. This condition is the highest conditions compared to only $1.9 \mathrm{wt} \%$ yield was obtained when extraction condition reduces to 200 bar. Another recent study also reporting on the same trend whereby the extraction of Portulaca oleracea at constant temperature of $333 \mathrm{~K}$ increases it yield from $49.75 \%$ to $85.0 \%$ when pressure was increased from $8 \mathrm{MPa}$ to24 MPa [39].

Temperature significantly affects the extraction rate. At constant pressure and flow rate of $30 \mathrm{MPa}$ and $4 \mathrm{~mL} / \mathrm{min}$, respectively, the extraction yield and mass transfer increases with increasing temperature from $50^{\circ} \mathrm{C}$ to $70^{\circ} \mathrm{C}$. The increment observed was from $3.2728 \mathrm{~m}^{3} / \mathrm{min}$ to $3.9623 \mathrm{~m}^{3} / \mathrm{min}$. The increases of temperature cause the vapour pressure of solute to increase thus, the extraction became rapid. Increase in temperature also increases the diffusivity of solute into the sample matrix. The same result was observed on the extraction of Quercus infectoria galls where, as the extraction temperature increases from $50^{\circ} \mathrm{C}$ to $70^{\circ} \mathrm{C}$ at constant pressure of $30 \mathrm{MPa}$, the $k_{f} a$ value increases from $6.72 \times 10^{-6} \mathrm{~ms}^{-1}$ to $8.20 \times 10^{-6} \mathrm{~ms}^{-1}$ [40]. A similar behaviour also may be observed on the extraction of Pithecellobium jiringan jack seed. As the pressure was kept constant at $41.38 \mathrm{MPa}$, the yield doubles from $3 \%$ to $6 \%$ when temperature was increased from $40^{\circ} \mathrm{C}$ to $80^{\circ} \mathrm{C}$ [41]. 


\section{CONCLUSION}

In a nut shell, the incorporation of simplified Sovová model with BIC model was successful in determining the mass transfer coefficient in solid and fluid phase. Furthermore, the AARD obtained in this study also shows that the data is acceptable to be use within the operating condition studied. The effect of the operating pressure, temperature and solvent flow rate on the mass transfer coefficient on solid and fluid phases was also discussed. The cross over pressure was found to be at $20 \mathrm{MPa}$. As for the future, it is suggested that the data is taken to be used for up-scaling as the solubility and mass transfer data is valuable for that purposes.

\section{ACKNOWLEDGEMENT}

This research is funded by Malaysian government under Research University Grant (GUP) (Vote no: R.J13000.7809.4F766). Ministry of Higher Education Malaysia with collaboration of Centre of Lipids Engineering and Applied Research (CLEAR), Universiti Teknologi Malaysia (UTM), Malaysia.

\section{REFERENCES}

[1] Dean JR. Extraction techniques in analytical science. Chichester, United Kingdom: John Wiley \& Sons, Ltd, 2009.

[2] Al-Darmaki N, Lu T, Al-Duri B, et al. Isothermal and temperature gradient supercritical fluid extraction and fractionation of squalene from palm fatty acid distillate using compressed carbon dioxide. The Journal of Supercritical Fluids 2012; 61: 108-114.

[3] Alexandre AMRC, Dias AMA, Seabra IJ, et al. Biodiesel obtained from supercritical carbon dioxide oil of Cynara cardunculus L. The Journal of Supercritical Fluids 2012; 68: 52-63.

[4] Barton P, Hughes RE, Hussein MM. Supercritical carbon dioxide extraction of peppermint and spearmint. The Journal of Supercritical Fluids 1992; 5: 157-162.

[5] Filho GL, De Rosso V V., Meireles MAA, et al. Supercritical CO2 extraction of carotenoids from pitanga fruits (Eugenia uniflora L.). The Journal of Supercritical Fluids 2008; 46: 33-39.

[6] Mezzomo N, Martínez J, Ferreira SRS. Supercritical fluid extraction of peach (Prunus persica) almond oil: Kinetics, mathematical modeling and scale-up. The Journal of Supercritical Fluids 2009; 51: 10-16.

[7] Simándi B, Kristo ST, Kéry Á, et al. Supercritical fluid extraction of dandelion leaves. The Journal of Supercritical Fluids 2002; 23: 135-142.

[8] Vargas CE, Mendes MF, Azevedo DA, et al. Extraction of the essential oil of abajeru (Chrysobalanus icaco) using supercritical CO2. The Journal of Supercritical Fluids 2010; 54: 171-177.

[9] Castro-Vargas HI, Rodríguez-Varela LI, Ferreira SRS, et al. Extraction of phenolic fraction from guava seeds (Psidium guajava L.) using supercritical carbon dioxide and co-solvents. The Journal of Supercritical Fluids 2010; 51: 319-324.

[10] Machmudah S, Martin A, Sasaki M, et al. Mathematical modeling for 
simultaneous extraction and fractionation process of coffee beans with supercritical CO2 and water. The Journal of Supercritical Fluids 2012; 66: 111119.

[11] Tonthubthimthong P, Douglas PL, Douglas S, et al. Extraction of nimbin from neem seeds using supercritical $\mathrm{CO} 2$ and a supercritical $\mathrm{CO} 2-$ methanol mixture. The Journal of Supercritical Fluids 2004; 30: 287-301.

[12] Danielski L, Michielin EMZ, Ferreira SRS. Horsetail (Equisetum giganteum L.) oleoresin and supercritical CO2: Experimental solubility and empirical data correlation. Journal of Food Engineering 2007; 78: 1054-1059.

[13] Chen C-R, Cheng Y-J, Ching Y-C, et al. Green production of energetic Jatropha oil from de-shelled Jatropha curcas L. seeds using supercritical carbon dioxide extraction. The Journal of Supercritical Fluids 2012; 66: 137-143.

[14] del Valle JM, Glatzel V, Martínez JL. Supercritical CO2 extraction of allicin from garlic flakes: Screening and kinetic studies. Food Research International 2012; 45: 216-224.

[15] Egydio JA, Moraes ÂM, Rosa PTV. Supercritical fluid extraction of lycopene from tomato juice and characterization of its antioxidation activity. The Journal of Supercritical Fluids 2010; 54: 159-164.

[16] Garcia VA dos S, Cabral VF, Zanoelo ÉF, et al. Extraction of Mucuna seed oil using supercritical carbon dioxide to increase the concentration of 1-Dopa in the defatted meal. The Journal of Supercritical Fluids 2012; 69: 75-81.

[17] Nguyen K, Barton P, Spencer JS. Supercritical carbon dioxide extraction of vanilla. The Journal of Supercritical Fluids 1991; 4: 40-46.

[18] Papamichail I, Louli V, Magoulas K. Supercritical fluid extraction of celery seed oil. The Journal of Supercritical Fluids 2000; 18: 213-226.

[19] Nagy B, Simándi B. Effects of particle size distribution, moisture content, and initial oil content on the supercritical fluid extraction of paprika. The Journal of Supercritical Fluids 2008; 46: 293-298.

[20] Da Porto C, Voinovich D, Decorti D, et al. Response surface optimization of hemp seed (Cannabis sativa L.) oil yield and oxidation stability by supercritical carbon dioxide extraction. The Journal of Supercritical Fluids 2012; 68: 45-51.

[21] Che Yunus MA, Naim Rozak M, Nian-Yian L, et al. Extraction of virgin coconut (Cocos nucifera) oil using supercritical fluid carbon dioxide. Jurnal Teknologi (Sciences and Engineering) 2014; 67: 11-15.

[22] Matan N, Saengkrajang W, Matan N. Antifungal activities of essential oils applied by dip-treatment on areca palm (Areca catechu) leaf sheath and persistence of their potency upon storage. International Biodeterioration \& Biodegradation 2011; 65: 212-216.

[23] Chang C-L, Wu R-T. Quantification of (+)-catechin and (-)-epicatechin in coconut water by LC-MS. Food Chemistry 2011; 126: 710-717.

[24] Bhandare A, Kshirsagar A, Vyawahare N, et al. Evaluation of anti-migraine potential of Areca catechu to prevent nitroglycerin-induced delayed inflammation in rat meninges: Possible involvement of NOS inhibition. Journal of Ethnopharmacology 2011; 136: 267-270.

[25] Hasan M, Mohd Azizi C, Othman N, et al. Extraction of catechin from Areca catechu Linn using Accelerated Solvent Extraction. In: Proceedings of South East Asia Conference. King Mongkut's University of Technology Thornburi, Thailand, 2012. 
[26] Sovová H. Rate of the vegetable oil extraction with supercritical CO2-I. Modelling of extraction curves. Chemical Engineering Science 1994; 49: 409414.

[27] Fiori L, Basso D, Costa P. Supercritical extraction kinetics of seed oil: A new model bridging the 'broken and intact cells' and the 'shrinking-core' models. The Journal of Supercritical Fluids 2009; 48: 131-138.

[28] Ruslan MSH, Idham Z, Nian Yian L, et al. Effect of operating conditions on catechin extraction from betel nuts using supercritical CO2-methanol extraction. Separation Science and Technology (Philadelphia) 2017; 00: 1-9.

[29] Özkal SG, Yener ME, Bayındırlı L. Mass transfer modeling of apricot kernel oil extraction with supercritical carbon dioxide. The Journal of Supercritical Fluids 2005; 35: 119-127.

[30] Rizza C. Experiments and Modelling of Supercritical CO2 Extraction of Lipids form Microalgae. Universita Degli Studi Di Padova, Italy, 2014.

[31] Pederssetti MM, Palú F, da Silva EA, et al. Extraction of canola seed (Brassica napus) oil using compressed propane and supercritical carbon dioxide. Journal of Food Engineering 2011; 102: 189-196.

[32] Chen Y-P, Chen Y-M, Tang M. Solubilities of cinnamic acid, phenoxyacetic acid and 4-methoxyphenylacetic acid in supercritical carbon dioxide. Fluid Phase Equilibria 2009; 275: 33-38.

[33] Sodeifian G, Ghorbandoost S, Sajadian SA, et al. Extraction of oil from Pistacia khinjuk using supercritical carbon dioxide: Experimental and modeling. Journal of Supercritical Fluids 2016; 110: 265-274.

[34] Rai A, Mohanty B, Bhargava R. Fitting of broken and intact cell model to supercritical fluid extraction (SFE) of sunflower oil. Innovative Food Science and Emerging Technologies 2016; 38: 32-40.

[35] Santos KA, Bariccatti RA, Cardozo-Filho L, et al. Extraction of crambe seed oil using subcritical propane: Kinetics, characterization and modeling. Journal of Supercritical Fluids 2015; 104: 54-61.

[36] Kupski SC, Klein EJ, da Silva EA, et al. Mathematical modeling of supercritical CO2 extraction of hops (Humulus lupulus L.). Journal of Supercritical Fluids 2017; 130: 347-356.

[37] de Melo MMR, Şen A, Silvestre AJD, et al. Experimental and modeling study of supercritical CO2extraction of Quercus cerris cork: Influence of ethanol and particle size on extraction kinetics and selectivity to friedelin. Separation and Purification Technology 2017; 187: 34-45.

[38] Vieitez I, Maceiras L, Jachmanián I, et al. Antioxidant and antibacterial activity of different extracts from herbs obtained by maceration or supercritical technology. Journal of Supercritical Fluids 2018; 133: 58-64.

[39] Sodeifian G, Ardestani NS, Sajadian SA, et al. Properties of Portulaca oleracea seed oil via supercritical fluid extraction: Experimental and optimization. Journal of Supercritical Fluids 2018; 135: 34-44.

[40] Mohd H, Salleh L, Syafiq M, et al. Single sphere model fitting of supercritical carbon dioxide extraction from Quercus infectoria galls. Malaysian Journal of Fundamental and Applied Sciences 2017; 13: 821-824.

[41] Yunus MAC, Zhari S, Haron S, et al. Extraction and identification of vitamin e from Pithecellobium jiringan seeds using supercritical carbon dioxide. Jurnal Teknologi 2015; 74: 29-33. 